\title{
Online Ratings of Hotels in Tirana and Durrës, Albania: An Econometric Analysis
}

\author{
Alma Braimllari \\ Department of Applied Mathematics, Faculty of Natural Sciences, University of Tirana, Albania
}

Copyright $\bigcirc 2017$ by authors, all rights reserved. Authors agree that this article remains permanently open access under the terms of the Creative Commons Attribution License 4.0 International License

\begin{abstract}
Online reviews are used by customers as an important source of information during the travel and tourism decision-making process. This research main objective is to analyze the online ratings of hotels in Tirana and Durrës, Albania. Data from Booking.com were collected for 132 hotels with 30 or more online reviews during the period of time 29 November - 2 December 2017. Mean of the overall online rating of hotels was 8.65 with a standard deviation of 0.636 . About $62.4 \%$ of online reviewers of hotels in Tirana have scored from 9 to 10 , and $44 \%$ of online reviewers of hotels in Durrës have scored from 9 to 10 . Results of two econometric models indicated that hotel's size and location negatively impact the overall online rating of the hotels, whereas the hotel's category, the number of online reviews and year the hotel was welcomed by Booking.com positively impact the overall online rating of hotels. These findings are useful for hotel guests and potential customers, and also for hotels' managers in developing appropriate marketing strategies.
\end{abstract}

Keywords Online Ratings, Booking.com, Hotel Sector, Logistic Model, Tobit Model

\section{Introduction}

Advancement in information and communication technology has recently affected the tourism sector. Travel websites are playing an increasing role in the tourism and hospitality industry, facilitating dynamic and effective interactions between hotels and their customers. In recent years, an increasing number of opinion platforms which offers consumer online reviews or product ratings are created. In order to help guests and potential customers to interact with each other, even the hotels are using their own review platforms [1]. At the pre-purchase evaluation stage, potential consumers rarely have access to all relevant information for making a decision regarding a product, and instead must use whatever cues or signals are available to evaluate the information's credibility [2]. Nowadays, hotel customers make purchase decisions based on friends' opinions, online ratings or other customers' comments posted online [3]. Online reviews have a strong impact on how the tourism and hospitality services are evaluated by the consumers [4]. Potential customers tend to trust online comments of other customers more than the recommendations of official destination marketing or hotel websites [5] and online hotel rating lists are perceived as more useful and more credible when they are published by well-known online travel communities [3]. In the study of [6] was found that with the increase of quality and quantity of online reviews, the buying intentions increase and also the authors suggest that the reviews generated by the user are believed to be more credible than information provided by suppliers of products and services. According to [7], with many years of experience on a platform, online reviewers tend to become more skilled and informed. In their study, [8] have found that online reviewers with higher reviewing expertise levels tend to post more negative reviews and lower ratings to signal their expertise. According to [9], business travelers tend to give lower online ratings, while couples tend to give higher online ratings. The cultural factor and travel experience play a significant role in the customers' online rating behavior [10]. Most recently, [11] have found enormous differences in the description of the hotel industry on various online review platforms, in particular, online reviews vary considerably.

For businesses, online reviews are intended as a means of persuasive communication in order to build credibility and influence the behavior of the user [5, 8]. Online evaluations represent a significant challenge for businesses, as they introduce direct competition and encourage consumer judgment cultures [12]. The study of [7] found a positive moderating effect of online reviewer trustworthiness on the relationship between the online reputation of a business and business sales. The results of [13] showed that positive online user recommendations influence positively and significantly the performance of tourism enterprises.

Besides online reviews, potential consumers utilize the 
expertise of the reviewer and responses to reviews posted by management [14]. The provision of a response also increases inferences that potential customers draw regarding the business's credibility and the extent to which it cares about its customers [2] and so can generate positive evaluations by hotel's consumers. Both online review experience and management response frequencies can positively affect customer satisfaction [15], which is critical for hotels' business survival [16].

In the study of [17] was compared the TripAdvisor scores and traditional customer satisfaction through travel intermediaries and was found that online reviews play a more significant role in explaining hotel performance metrics than traditional feedback. The study of [18] analyzed the online ratings of 110 hotels using the data of Booking.com and TripAdvisor and has found high correlation between the online ratings of hotels in Booking.com and TripAdvisor; also, the hotel's size and category negatively influence the online rating, while the number of online reviewers has a positive influence on online rating. The study of [19] analyzed the online ratings of 220 hotels in Albania and it was found that the hotel's category and the number of online reviews positively impact the overall online rating, whereas the hotel's size and region negatively impact the overall online rating of the hotels.

The Travel and Tourism Economic Impact 2017 report for Albania [20] indicated that the direct contribution of Travel \& Tourism to GDP was $8.4 \%$ of GDP in 2016 and it is forecast to rise by $5.2 \%$ in 2017 . The total contribution of Travel \& Tourism to GDP was $26.0 \%$ of GDP in 2016 and is expected to grow by $5.3 \%$ to $26.4 \%$ of GDP in 2017 . Travel \& Tourism directly supported $7.7 \%$ of total employment in 2016 and is expected to rise by $3.2 \%$ in 2017. The total contribution of Travel \& Tourism to employment was $23.9 \%$ of total employment in 2016 and is expected to rise by $3.2 \%$ in 2017.

The hotel industry is essential for the provision of all other tourism services, it is the first service demanded by tourists who reach the destination, and it carries a high weight in the totality of tourist expenditure. For these two reasons, this study focuses on the hotel industry within the tourism sector in Tirana and Durrës cities, in Albania.

The Booking.com is the world leader in online hotel bookings, followed by TripAdvisor. Every day more than 1.5 million room nights are reserved on Booking.com platform [21]. Since the number of hotels located in Tirana and Durrës in Booking.com was higher compared to TripAdvisor and in Booking.com only the guests who have booked a hotel from it can give their opinions about a hotel stay, in this study was selected the database of Booking.com.

The aim of this study was to analyze the online ratings of 132 hotels in Tirana and Durrës using a database of Booking.com. To evaluate the influence that the hotel's size, location, category, the year that the hotel was welcomed by Booking.com and the number of online reviews have on the overall online rating of hotels were used two econometric models, logistic regression, and Tobit regression.

\section{Materials and Methods}

The target population of this study consists of hotels operating in Tirana and Durrës. The sample was comprised of 94 hotels located in Tirana and 38 hotels located in Durrës with 30 or more online reviews. The data from Booking.com were collected from 29 November to 2 December 2017. Information about online reviewers' score (ranging from 0 to 10) for cleanliness, comfort, location, facilities, staff, value for money, Free $\mathrm{Wi}-\mathrm{Fi}$, and overall online rating; information about the tangible facilities and offered services, hotel category (star number), hotel size (number of rooms), the number of online reviews, the type of guests, the year since the Booking.com has welcomed the hotel, and tangible facilities and offered services were gathered and analyzed.

The Welch's t-test was used to compare the means of overall online rating, and seven dimensions of performance for hotels in Tirana and Durrës.

To identify the factors influencing the overall online rating of hotels, the logistic regression and the Tobit regression model were estimated.

A logistic regression model with a binary response was modeled. Logistic regression allows estimating probabilities of the response occurring [22]. The logistic regression equation takes the following form

$$
\ln \left(\frac{p}{1-p}\right)=\beta_{0}+\beta_{1} x_{1}+\beta_{2} x_{2}+\ldots+\beta_{k} x_{k}
$$

where $p$ is the estimated probability that a hotel to have an overall online rating ranging from 9 to 10 , and $x_{1}, x_{2}, \ldots, x_{k}$ are independent or explanatory variables of the model. The estimated probability of the response occurring $(p)$ divided by the probability of it not occurring $(1-p)$ is called the odds ratio (OR).

The Tobit regression model was also used to identify the factors influencing the overall online rating of hotels in Albania. Since online reviewers score was bounded, it is appropriate to use a limited dependent variable approach. The Tobit regression model is employed when the dependent variable is bounded from below or above or both with positive probability pileup at the interval ends, either by being censored or by being cornered solution [23]. The two-limit Tobit model, when values of $y$ are bounded by 0 and 1 , is given as:

$$
\begin{gathered}
y_{i}^{*}=\beta_{0}+\beta_{1} x_{i 1}+\ldots+\beta_{k} x_{i k}+\varepsilon_{i} \\
y_{i}=\left\{\begin{array}{cc}
y_{i}^{*} & 0 \leq y_{i}^{*} \leq 1 \\
0 & y_{i}^{*}<0 \\
1 & y_{i}^{*}>1
\end{array}\right.
\end{gathered}
$$


where $\varepsilon_{i} \sim N\left(0, \sigma^{2}\right), \quad x_{1}, x_{2}, \ldots, x_{k}$ are explanatory variables and $\beta$ are unknown parameters. The variable $y_{i}^{*}$ is a latent variable and $y_{i}$ is the dependent variable, the overall online rating of the hotels.

STATA was used to conduct the analysis of the data.

\section{Results and Discussion}

About 71\% (94) of the hotels in the sample were located in Tirana and $42.4 \%$ of the hotels had from 10 to 19 rooms, $42.4 \%$ of them were 3 -star hotels. Also $43 \%$ of the hotels had from 30 to 100 online reviews and $38.6 \%$ of them have been welcomed by Booking.com during the period 2011-2012 (Table 1, Appendix). About 76.5\% of the hotels offered free parking, $73 \%$ offered room service, $57 \%$ had a restaurant, and about half of them offered family rooms (Table 2, Appendix).

About $62.4 \%$ of online reviewers of hotels in Tirana have scored from 9 to 10 (superb) and 30\% of them have scored from 7 to 9 (good), whereas about $44 \%$ of online reviewers of hotels in Durrës have scored from 9 to 10 and about $39 \%$ of them have scored from 7 to 9 . Among online reviewers of hotels in Tirana, about $31 \%$ of them were couples, 24\% were solo travelers and 19.5\% were business travelers. While among online reviewers of hotels in Durrës, about $41 \%$ were couples, $23.6 \%$ were families and $16.6 \%$ were group of friends (fig. 1).

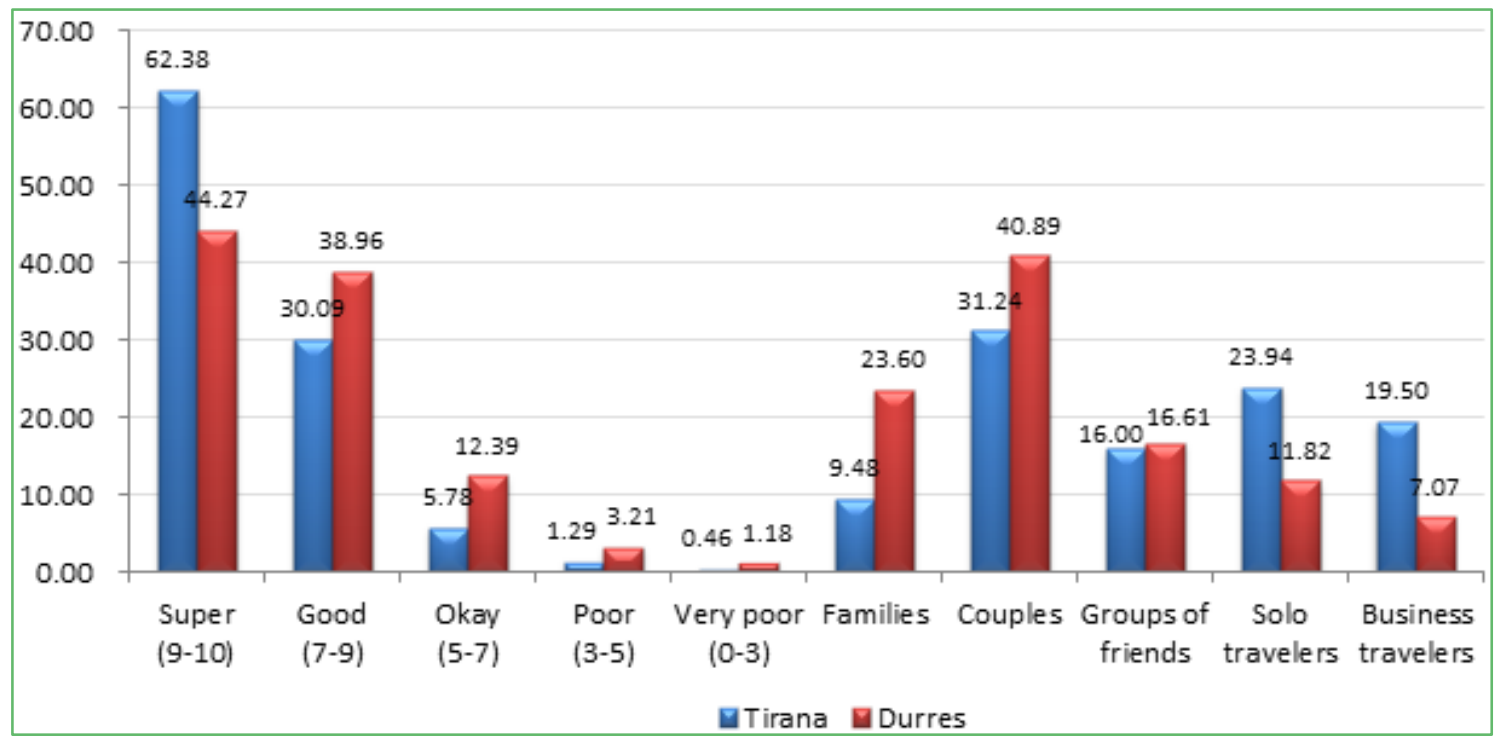

Figure 1. Percentage of online reviewers according to their score and according to their type

The mean overall online rating for hotels in the sample was 8.65 with a standard deviation of 0.636. For hotels in Tirana, the mean overall online rating was 8.82 and standard deviation was 0.533 , while for hotels in Durrës the mean was 8.23 and standard deviation 0.684 .

The mean and standard deviation of overall online rating and each dimension of performance, as well as difference between means were calculated (table 1). The difference between the means was defined as mean of hotels in Tirana minus mean of hotel in Durrës. The results of hypothesis testing indicated a significant and positive difference in means at the $1 \%$ level for each variable.

Table 1. Results of testing differences between two means

\begin{tabular}{|c|c|c|c|c|c|}
\hline & \multicolumn{2}{|c|}{ Hotels in Tirana } & \multicolumn{2}{c|}{ Hotels in Durrës } & $\begin{array}{c}\text { Difference between } \\
\text { two means }\end{array}$ \\
\cline { 2 - 6 } & Mean & Standard deviation & Mean & Standard deviation & $0.583^{*}$ \\
\hline Overall & 8.817 & 0.533 & 8.234 & 0.684 & $0.697^{*}$ \\
\hline Cleanliness & 9.034 & 0.652 & 8.337 & 0.891 & $0.548^{*}$ \\
\hline Comfort & 8.624 & 0.721 & 8.076 & 0.753 & $0.576^{*}$ \\
\hline Facilities & 8.405 & 0.717 & 7.829 & 0.789 & $0.407^{*}$ \\
\hline Staff & 9.149 & 0.537 & 8.742 & 0.684 & $0.481^{*}$ \\
\hline $\begin{array}{c}\text { Value for } \\
\text { money }\end{array}$ & 8.763 & 0.536 & 8.281 & 0.716 & $0.931^{*}$ \\
\hline Free Wi-Fi & 8.731 & 0.899 & 7.800 & 1.626 & $0.765^{*}$ \\
\hline Location & 8.904 & 0.607 & 8.139 & 0.880 & $0^{*}$ \\
\hline
\end{tabular}

Note: $* \mathrm{p}<0.01$. Ha: $\mu_{\mathrm{Tr}}>\mu_{\mathrm{Dr}}$ 


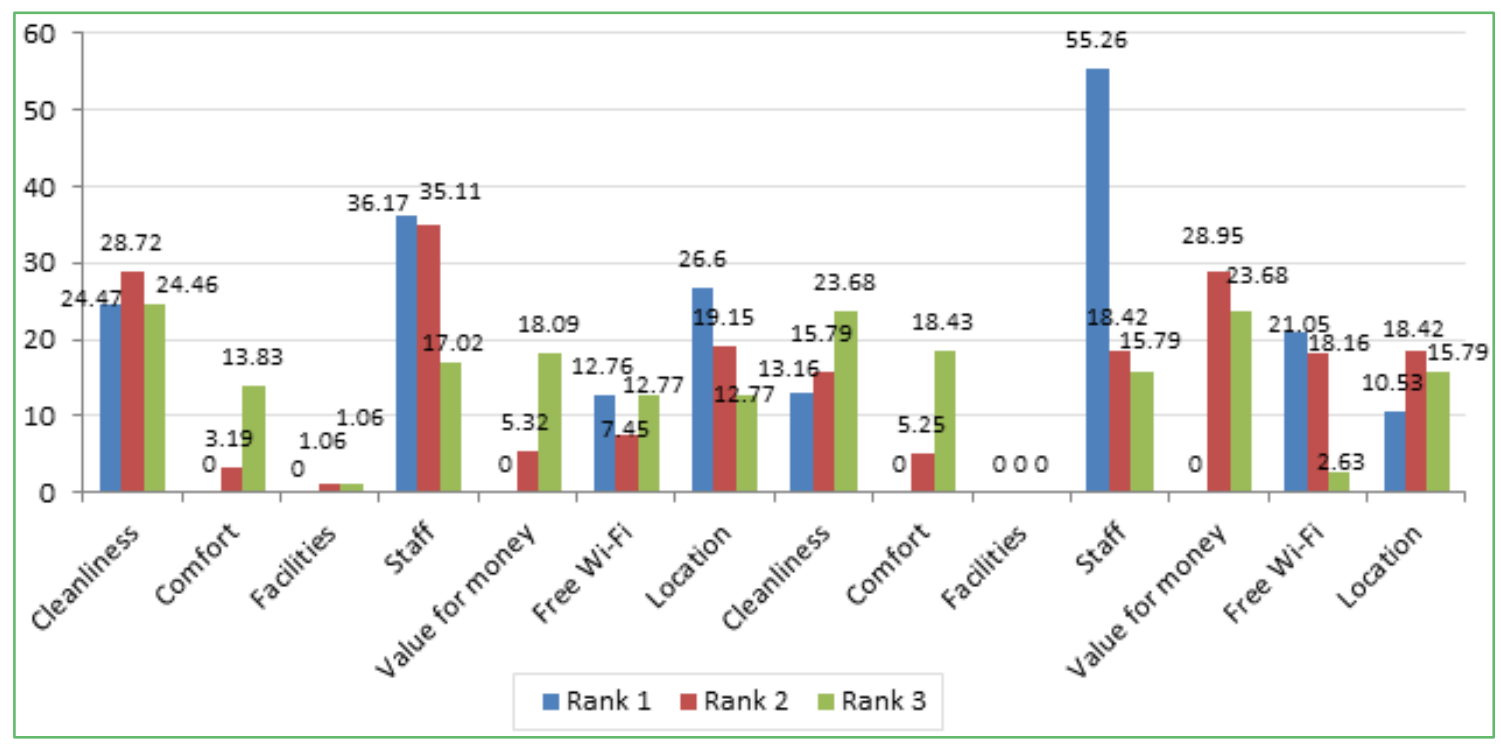

Figure 2. Percentage of hotels according to the online reviewers scores

For hotels in Tirana: the staff had the highest score for $36.2 \%$ of the hotels and for $26.6 \%$ of them the location had the highest score; the second highest reviewers score was the staff for $35 \%$ of the hotels, for $28.7 \%$ was the cleanliness and for $19 \%$ was location; for $24.5 \%$ of the hotels the third highest score was cleanliness and for $18 \%$ of the hotels was the value for money (fig. 2).

For hotels in Durrës: the staff had the highest score for $55 \%$ of the hotels and for $21 \%$ of them the free Wi-Fi had the highest score; the second highest reviewers score was the value for money for $29 \%$ of the hotels, for $18.4 \%$ was the staff, and for $18.4 \%$ was the location; for $24 \%$ of the hotels the third highest score was cleanliness and for $24 \%$ of them was the value for money (fig. 2).

Two econometrics models were evaluated using the available data; binary logistic regression and Tobit regression. The correlation matrix of independent variables of the models (table 3, Appendix) indicated that all correlation coefficients were statistically significant at $5 \%$ level.

The results of two binary logistic regression models are shown in table 2. The results of the logistic model 2 indicated that the model was statistically significant (LR chi-square $(11)=46.04, p<0.01)$. The value of Pseudo- $R^{2}$ was $26.3 \%$ and the percentage of cases correctly classified was $77.3 \%$. The classification accuracy should be at least $75 \%$ [24].

The results of the logistic model 2 indicated that the overall online rating was negatively and no significantly influenced by the hotel's size, that is, the hotels with 25 or more rooms were less likely to score from 9 to 10 by online reviewers $(\mathrm{OR}=0.619)$. This finding was consistent with the finding [18]. The results of [19] indicated a negative and significant influence of the hotel size on overall online rating of hotels.

The overall online rating was positively influenced by the hotel's category at the $1 \%$ level, indicating that 4 or 5 -star hotels were more likely to have an overall online rating from 9 to $10(\mathrm{OR}=6.946)$. This finding was consistent with the finding [19]. In the study of [18] was found a negative and no significant impact of hotel category on the online rating. 
Table 2. Results of logistic models

\begin{tabular}{|c|c|c|c|c|}
\hline \multirow{2}{*}{ Independent variable } & \multicolumn{2}{|c|}{ Model 1} & \multicolumn{2}{|c|}{ Model 2} \\
\hline & Coef. & OR & Coef. & OR \\
\hline \multicolumn{5}{|l|}{ Size } \\
\hline $\begin{array}{l}\text { Less than } 25 \text { rooms } \\
25 \text { or more rooms }\end{array}$ & -0.344 & $\begin{array}{l}1.000 \\
0.709 \\
\end{array}$ & -0.480 & $\begin{array}{l}1.000 \\
0.619\end{array}$ \\
\hline \multicolumn{5}{|l|}{ Category } \\
\hline $\begin{array}{c}4 \text { to } 5 \text { stars } \\
3 \text { or } 2 \text { stars or unrated }\end{array}$ & $1.621^{* *}$ & $\begin{array}{c}5.059^{* *} \\
1.000\end{array}$ & $1.938^{* *}$ & $\begin{array}{c}6.946^{* *} \\
1.000\end{array}$ \\
\hline \multicolumn{5}{|l|}{ Number of online reviews } \\
\hline $\begin{array}{c}30 \text { to } 100 \\
101 \text { to } 200 \\
\text { More than } 200\end{array}$ & $\begin{array}{l}0.877^{+} \\
1.257^{*} \\
\end{array}$ & $\begin{array}{l}1.000 \\
2.404^{+} \\
3.514^{*} \\
\end{array}$ & $\begin{array}{l}1.023^{+} \\
1.525^{* *} \\
\end{array}$ & $\begin{array}{l}1.000 \\
2.781^{+} \\
4.597^{* *} \\
\end{array}$ \\
\hline \multicolumn{5}{|l|}{ Location/City } \\
\hline $\begin{array}{l}\text { Tiranë } \\
\text { Durrës }\end{array}$ & $-2.136^{* *}$ & $\begin{array}{l}1.000 \\
0.118^{* *}\end{array}$ & $-1.896^{* *}$ & $\begin{array}{l}1.000 \\
0.150^{* *}\end{array}$ \\
\hline \multicolumn{5}{|l|}{ Starting year in Booking.com } \\
\hline $\begin{array}{l}2011-2013 \\
2014-2017 \\
\end{array}$ & $1.287^{* *}$ & $\begin{array}{c}1.000 \\
3.624^{* *}\end{array}$ & $1.371^{* *}$ & $\begin{array}{l}1.000 \\
3.939^{* *}\end{array}$ \\
\hline \multicolumn{5}{|l|}{ Facilities and services: } \\
\hline Restaurant & & & $-1.095^{*}$ & $0.335^{*}$ \\
\hline Room service & & & 0.266 & 1.305 \\
\hline Family rooms & & & 0.107 & 1.113 \\
\hline Facilities for disabled guests & & & 0.360 & 1.433 \\
\hline Free parking & & & 0.400 & 1.492 \\
\hline Constant & $-1.953^{* *}$ & $0.142^{* *}$ & $-2.296^{* *}$ & $0.100^{* *}$ \\
\hline $\begin{array}{l}\text { LR chi-square }(\mathrm{df}) \\
\text { Pseudo-R2 } \\
\% \text { correctly classified }\end{array}$ & & & & \\
\hline
\end{tabular}

Note: $+\mathrm{p}<0.10, * \mathrm{p}<0.05, * * \mathrm{p}<0.01$.

The overall online rating was positively influenced by the number of online reviews at the $1 \%$ level. This means that hotels with more than 200 online reviews were more likely to score an overall online rating from 9 to $10(\mathrm{OR}=$ 4.597). This finding was consistent with the findings of [18] and [19].

The location/city of the hotels negatively influenced the overall online rating at the $1 \%$ level, that is, the hotels located in Durrës were less likely to score 9 to 10 by online reviewers $(\mathrm{OR}=0.150)$. In their study, [19] found that region had a negative and significant influence on the overall online rating. In his study, [25] found that the performance of the hotel companies is significantly influence by the type and location of the hotel.

The year that hotel was welcomed by Booking.com positively influenced the overall online rating of hotels at the $5 \%$ level, that is, the hotels welcomed by booking.com in years 2014-2017 were more likely to score from 9 to 10 by online reviewers $(\mathrm{OR}=3.939)$.

The results indicated that tangible facilities and offered services have positive and no significant influence on the overall online rating, except for the restaurant. This indicated that the overall online rating of the hotels did not depend on its tangible facilities and offered services, but the service quality. In the study of [18] was found that total rating of hotels was not influenced by its tangible facilities and offered services, with one exception for Free Wi-Fi.

The robustness of the independent variables that influence the overall online rating was checked by estimating the Tobit regression model. The results of two Tobit models are shown in table 3.

The results of the Tobit model 2 indicated that the model was statistically significant (LR chi-square (11) = 46.72, $\mathrm{p}<0.01)$. The value of Pseudo- $\mathrm{R}^{2}$ was $18.4 \%$. The results of the Tobit model 2 showed that the hotel's size and location/city had a negative effect on overall online rating, whereas hotel's category and the number of online reviews had a positive effect on overall online rating of hotels. These findings were consistent with the findings of [19]. The year that the hotel was welcomed by Booking.com had a positive effect on overall online rating of hotels at the $10 \%$ level. 
Table 3. Results of Tobit models (coefficients)

\begin{tabular}{|c|c|c|}
\hline Independent variable & Model 1 & Model 2 \\
\hline \multicolumn{3}{|l|}{ Size } \\
\hline $\begin{array}{c}\text { Less than } 25 \text { rooms } \\
25 \text { or more rooms }\end{array}$ & -0.166 & $-0.200^{+}$ \\
\hline \multicolumn{3}{|l|}{ Category } \\
\hline $\begin{array}{c}4 \text { to } 5 \text { stars } \\
3 \text { or } 2 \text { stars or unrated }\end{array}$ & $0.350^{* *}$ & $0.340^{* *}$ \\
\hline \multicolumn{3}{|l|}{ Number of online reviews } \\
\hline $\begin{array}{c}30 \text { to } 100 \\
101 \text { to } 200 \\
\text { More than } 200\end{array}$ & $\begin{array}{l}0.265^{*} \\
0.313^{* *}\end{array}$ & $\begin{array}{l}0.277^{*} \\
0.344^{* *}\end{array}$ \\
\hline \multicolumn{3}{|l|}{ Location/City } \\
\hline $\begin{array}{l}\text { Tirana } \\
\text { Durrës }\end{array}$ & $-0.503^{* *}$ & $-0.478^{* *}$ \\
\hline \multicolumn{3}{|l|}{ Starting year in Booking.com } \\
\hline $\begin{array}{l}2011-2013 \\
2014-2017 \\
\end{array}$ & $0.173^{+}$ & $0.165^{+}$ \\
\hline \multicolumn{3}{|l|}{ Facilities and services: } \\
\hline Restaurant & & -0.088 \\
\hline Room service & & 0.068 \\
\hline Family rooms & & -0.010 \\
\hline Facilities for disabled guests & & 0.096 \\
\hline Free parking & & 0.107 \\
\hline Constant & $8.437^{* *}$ & $8.344^{* *}$ \\
\hline Sigma & 0.535 & 0.530 \\
\hline $\begin{array}{l}\text { LR chi-square (df) } \\
\text { Pseudo-R2 }\end{array}$ & $\begin{array}{l}44.5(6)^{* *} \\
17.53 \%\end{array}$ & $\begin{array}{c}46.7(11)^{* *} \\
18.4 \%\end{array}$ \\
\hline
\end{tabular}

Note: $+\mathrm{p}<0.10 * \mathrm{p}<0.05, * * \mathrm{p}<0.01$.

Also, the results of the Tobit model 2 indicated that tangible facilities and offered services did not influence significantly the overall online rating of the hotels at the 5\% level. The competition between tourist destinations is affected by the quality offered by hotels in the region, and for this reason, to add value to the hotel and to the region is necessary to provide quality services and to pay attention to the customer needs and customer satisfaction [26]. The study of [27] indicated that the availability of recently-added amenities and green practice initiatives, have a positive influence on customers' overall ratings and hotel performance. Also, [28] found that green practices were positively related to guest satisfaction and return intentions. The results of [16] indicated that "tangible and sensorial experience, staff aspect, aesthetic perception, and location" significantly and positively influence the customer satisfaction.

\section{Conclusions}

With the development of information and communication technology, customers are increasingly sharing their experiences on consumer-generated online review websites. These websites have become a main source of information not only for customers' decision on a hotel stay, but also for hotel managers trying to understand their customers and competitors. Online reviews can help customers to reduce uncertainty and risks faced in online shopping. The goal of this research was to analyze the online guest ratings of 132 hotels located in Tirana and Durrës, Albania.

The results of the descriptive analysis indicated that the mean overall online rating for the hotels in the sample was 8.65. About $62 \%$ of online reviewers of hotels in Tirana have scored from 9 to 10 , indicating that $62 \%$ of online reviewers awarded scores that reflect very good experiences during their hotel stays in Tirana. About 44\% of online reviewers of hotels in Durrës have scored from 9 to 10 , indicating that $44 \%$ of online reviewers awarded scores that reflect very good experiences during their hotel stays in Tirana. The staff had the highest score for $36 \%$ of the hotels in Tirana, and for about 55\% of hotels in Durrës. The results of Welch's t-test indicated statistically significant and positive differences between the means of overall online rating and seven dimensions of performance for hotels in Tirana and Durrës.

The results of logistic and Tobit models indicated that hotel's size and location negatively impacted the overall online rating of the hotels, whereas the hotel's category, the number of online reviews and the year the hotel was welcomed by Booking.com positively impacted the overall online rating of hotels. More specifically, the results of binary logistic regression indicated that hotels with less than 25 rooms, 4 or 5 -star hotels, hotels with more than 200 online reviews, hotels located in Tirana and hotels welcomed by Booking.com in years 2014-2017 were more likely to score from 9 to 10 by online reviewers. The results indicated that tangible facilities and offered services did not influence significantly the overall online rating of the hotels, thus to add value to the hotels is necessary to provide quality services.

With these findings, this study contributes to the current debate on the factors influencing the online hotel rating. This research provided evidence about the impact of some hotels characteristics on the customers' overall online rating and it focuses on the online ratings generated by Booking.com. The results of this research suggest that the hotels' managers should pay attention to the online reviews provided by the hotel guests. The hotels' managers must encourage their guests to write honest reviews about their stay since the number of online reviews positively influence the overall online rating of the hotels in the Booking.com. Moreover, hotel managers need to carefully respond to reviews, as responses to reviews posted by management can positively influence customer satisfaction and can generate positive evaluations by guests of a hotel. The findings of this study can be used by potential customers, hotel guests, and by hotels' managers to increase the online ratings of their hotels and customer satisfaction.

The findings of this study have some limitations. Firstly, the analysis of the data was conducted using data from one 
commercial online booking website. Second, the analyzed data are cross-sectional. Third, this study examined some of the factors influencing the overall online rating of hotel guests. Other factors such as reviewers' characteristics (travel experience, personality, culture, etc) can affect their evaluation of hotel attributes and hotel performance. In the future, this research can be extended comparing the online ratings of hotels generated by different websites; analyzing a panel dataset and also the impact of online reviewers' characteristics on online hotel rating.

\section{Appendix}

Table 1. Descriptive statistics of hotels in the sample

\begin{tabular}{|c|c|c|}
\hline Variable & Frequency & Percentage \\
\hline $\begin{array}{c}\text { Hotel Size: } \\
\text { Less than } 10 \text { rooms } \\
10-19 \text { rooms } \\
20-29 \text { rooms } \\
30-49 \text { rooms } \\
50 \text { or more rooms }\end{array}$ & $\begin{array}{l}21 \\
56 \\
30 \\
12 \\
13\end{array}$ & $\begin{array}{c}15.91 \\
42.42 \\
22.73 \\
9.09 \\
9.85 \\
\end{array}$ \\
\hline $\begin{array}{c}\text { Hotel category: } \\
\text { 5-star } \\
4 \text {-star } \\
\text { 3-star } \\
\text { 2-star } \\
\text { 1-star } \\
\text { Unrated } \\
\end{array}$ & $\begin{array}{c}6 \\
55 \\
56 \\
4 \\
1 \\
10\end{array}$ & $\begin{array}{c}4.55 \\
41.67 \\
42.42 \\
3.03 \\
0.76 \\
7.58 \\
\end{array}$ \\
\hline $\begin{array}{c}\text { Location/city: } \\
\text { Tirana } \\
\text { Durrës } \\
\end{array}$ & $\begin{array}{l}94 \\
38 \\
\end{array}$ & $\begin{array}{l}71.21 \\
28.79 \\
\end{array}$ \\
\hline $\begin{array}{c}\text { Number of online reviews: } \\
30-100 \\
101-200 \\
>200 \\
\end{array}$ & $\begin{array}{l}57 \\
36 \\
39 \\
\end{array}$ & $\begin{array}{l}43.18 \\
27.27 \\
29.55 \\
\end{array}$ \\
\hline $\begin{array}{c}\text { Starting Year in Booking.com: } \\
\text { 2011-2012 } \\
2013-2014 \\
2015-2017 \\
\end{array}$ & $\begin{array}{l}51 \\
41 \\
40 \\
\end{array}$ & $\begin{array}{l}38.64 \\
31.06 \\
30.30 \\
\end{array}$ \\
\hline Total & 132 & 100 \\
\hline
\end{tabular}

Table 2. Descriptive statistics of some facilities and services of hotels in the sample

\begin{tabular}{|c|c|c|}
\hline Facilities and services: & Frequency & Percentage \\
\hline Swimming pool & 21 & 13.91 \\
\hline Fitness center & 18 & 13.64 \\
\hline Spa & 18 & 56.82 \\
\hline Restaurant & 75 & 72.73 \\
\hline Room service & 96 & 50.76 \\
\hline Family rooms & 67 & 15.15 \\
\hline Facilities for disabled guests & 20 & 76.52 \\
\hline
\end{tabular}

Table 3. Correlation matrix between independent variables

\begin{tabular}{|c|c|c|c|c|c|c|c|c|c|c|}
\hline & 1 & 2 & 3 & 4 & 5 & 9 & 10 & 11 & 12 & 13 \\
\hline 1.Size & 1.000 & & & & & & & & & \\
\hline 2.Location & $0.024^{*}$ & 1.000 & & & & & & & & \\
\hline 3.Category & $0.285^{*}$ & $-0.086^{*}$ & 1.000 & & & & & & & \\
\hline 4.Reviews & $0.255^{*}$ & $-0.171^{*}$ & $0.035^{*}$ & 1.000 & & & & & & \\
\hline 5.Starting year in Booking.com & $-0.131^{*}$ & $0.010^{*}$ & $-0.208^{*}$ & $-0.025^{*}$ & 1.000 & & & & & \\
\hline 9.Restaurant & $0.156^{*}$ & $0.284^{*}$ & $0.287^{*}$ & $0.073^{*}$ & $-0.091^{*}$ & 1.000 & & & & \\
\hline 10.Room service & $0.184^{*}$ & $-0.024^{*}$ & $0.192^{*}$ & $-0.063^{*}$ & $-0.143^{*}$ & $0.222^{*}$ & 1.000 & & & \\
\hline 11.Family rooms & $-0.009^{*}$ & $0.325^{*}$ & $-0.059^{*}$ & $0.109^{*}$ & $0.017^{*}$ & $0.212^{*}$ & $0.009^{*}$ & 1.000 & & \\
\hline 12.Facilities for disabled guests & $0.263^{*}$ & $-0.035^{*}$ & $0.244^{*}$ & $0.197^{*}$ & $0.009^{*}$ & $0.155^{*}$ & $0.069^{*}$ & $0.078^{*}$ & 1.000 & \\
\hline 13.Free parking & $0.098^{*}$ & $0.155^{*}$ & $0.155^{*}$ & $-0.179^{*}$ & $0.022^{*}$ & $0.239^{*}$ & $0.222^{*}$ & $0.026^{*}$ & $0.085^{*}$ & 1.000 \\
\hline
\end{tabular}

Note: $* \mathrm{p}<0.05$ 


\section{REFERENCES}

[1] M. L. Kasavana, K. Nusair, and K. Teodosic. Online social networking: redefining the human web. Journal of Hospitality and Tourism Technology, 1(1), 68-82, 2010.

[2] B. A. Sparks, K. K. F. So, and G. L. Bradley. Responding to negative online reviews: The effects of hotel responses on customer inferences of trust and concern. Tourism Management, 53, 74-85, 2016.

[3] L.V. Casaló, C. Flavián, M. Guinalíu and Y. Ekinci. Do online hotel rating schemes influence booking behaviors? International Journal of Hospitality Management, 49, 28-36, 2015. http://doi.org/10.1016/j.ijhm.2015.05.005

[4] V. Browning, K. K. F. So, and B. A. Sparks. The influence of online reviews on consumers' attributions of service quality and control for service standards in hotels. Journal of Travel \& Tourism Marketing, 30(1-2), 23-40, 2013.

[5] B. A. Sparks, H. E. Perkins and R. Buckley. Online travel reviews as persuasive communication: The effects of content type, source, and certification logos on consumer behavior. Tourism Management, 39, 1-9, 2013.

[6] D.H. Park, J. Lee and I. Han. The effect of online consumer reviews on consumer purchasing intention: The moderating role of involvement. International Journal of Electronic Commerce, 11 (4), 125-48, 2007.

[7] S. Banerjee, S. Bhattacharyya, and I. Bose. Whose online reviews to trust? Understanding reviewer trustworthiness and its impact on business. Decision Support Systems, 96, 17-26, 2017.

[8] Z. Zhang, Z. Zhang, and Y. Yang. The power of expert identity: How web-site recognized expert reviews influence traveler's online rating behavior, Tourism Management, 55, 15-24, 2016

[9] Y. C. Chang, C. H. Ku, and C. H. Chen. Social media analytics: Extracting and visualizing Hilton hotel ratings and reviews from TripAdvisor. International Journal of Information Management. November 2017, https://doi.org/10.1016/j.ijinfomgt.2017.11.001

[10] B. Gao, X. Li, S. Liu, dhe D. Fang. How power distance affects online hotel ratings: The positive moderating roles of hotel chain and reviewers' travel experience. Tourism Management, 65, 176-186, 2018.

https://doi.org/10.1016/j.tourman.2017.10.007

[11] Z. Xiang, Q. Du, Y., Ma, and W. Fan. A comparative analysis of major online review platforms: Implications for social media analytics in hospitality and tourism. Tourism Management, 58, 51-65, 2017.

[12] S. Gössling, C. M. Hall, and A.C. Anderson. The manager's dilemma: a conceptualization of online review manipulation strategies. Current Issues in Tourism, Vol. 21, Iss. 5, 2018. https://doi.org/10.1080/13683500.2015.1127337

[13] P. Phillips, S. Barners, K. Zigan and R. Schegg. Understanding the impact of online reviews on hotel performance: An empirical analysis. Journal of Travel
Research, 27, 1-15, 2016.

[14] K. L. Xie, and K. K. F. So. The Effects of Reviewer Expertise on Future Reputation, Popularity, and Financial Performance of Hotels: Insights From Data-Analytics. Journal of Hospitality \& Tourism Research, December 2017. http://journals.sagepub.com/doi/pdf/10.1177/10963480177 44016.

[15] S. Liang, M., Schuckert, and R. Law, R. Multilevel analysis of the relationship between type of travel, online ratings, and management response: Empirical evidence from international upscale hotels. Journal of Travel \& Tourism Marketing, 34(2), 239-256, 2017.

[16] L. Ren, H., Qiu, P., Wang, and P.M. Lin. Exploring customer experience with budget hotels: dimensionality and satisfaction, International Journal of Hospitality Management, Vol. 52, 13-23, 2016.

[17] W. G. Kim, and S. A. Park. Social media review rating versus traditional customer satisfaction: Which one has more incremental predictive power in explaining hotel performance? International Journal of Contemporary Hospitality Management, 29(2), 784-802, 2017.

[18] D. Ilieva and S. H. Ivanov. Analysis of online hotel ratings: the case of Bansko, Bulgaria. 2014. Online available from https://ssrn.com/abstract=2496523

[19] A. Braimllari and E. Sala. An Econometric Analysis of Online Ratings of Hotels in Albania, In Proc. 13th International conference of ASECU "Social and Economic Challenges in Europe 2016 - 2020" May 19-20, Durrës, Albania. pp $296-304,2017$

[20] The travel and Tourism economic Impact 2017, Albania: Online available from https://www.wttc.org/-/media/files/reports/economic-impac t-research/countries-2017/albania2017.pdf

[21] Princeline Group, Booking.com. Online available from https://www.pricelinegroup.com/booking-com/

[22] D.W. Hosmer, S. Lemeshow, and R.X. Sturdivant. Applied logistic regression. 2013

[23] J.M. Wooldridge. Econometric analysis of cross-section and panel data. MIT press, 2010.

[24] J.F. Hair, W. Black, B.J. Babin and R.E. Anderson. Multivariate Data Analysis, 2009.

[25] S. Lee. Internationalization of US multinational hotel companies: expansion to Asia versus Europe. International Journal of Hospitality Management, 27(4), 657-664, 2008.

[26] G. Santoro. Evaluating performance in the hotel industry: An empirical analysis of Piedmont. Journal of Investment and Management, 4(1-1): 17-22, 2015.

[27] W. G. Kim, J. Li, J. S. Han, and Y. Kim. The influence of recent hotel amenities and green practices on guests' price premium and revisit intention. Tourism Economics 23, no. 3, 577-593, 2017.

[28] O. Berezan, C. Raab, M. Yoo, and C. Love. Sustainable hotel practices and nationality: The impact on guest satisfaction and guest intention to return. International Journal of Hospitality Management, 34, 227-233, 2013. 